\title{
Editorial: The Judgment of Princeton and Other Articles
}

\author{
Orley Ashenfelter ${ }^{a}$ and Karl Storchmann ${ }^{b}$
}

At its $6^{\text {th }}$ Annual Conference in Princeton, the American Association of Wine Economists organized a wine tasting that was modeled after the 1976 Judgment of Paris. Subsequently, this tasting has been called the Judgment of Princeton.

At the original Paris event in 1976, British wine merchant Steve Spurrier organized two blind tastings with nine French wine judges who were associated with the wine industry in various ways (wine journalists, critics, sommeliers, merchants or winemakers). In the first flight, the judges rated ten white wines - six from Napa and four from Burgundy. In the second flight, the judges rated ten reds - six from Napa and four from Bordeaux. In both tastings a wine from Napa, a then relatively unknown wine region, was declared the winner. George Taber of TIME magazine, the only attending journalist, reported the surprising results to the world, and helped to put Napa, a then nascent wine region, on the global wine map.

At the Princeton event, this time led by George Taber, nine wine judges from France, Belgium and the U.S. tasted French and New Jersey wines in a process designed to emulate what occurred in France in 1976. As in Napa in 1976, the quality wine industry in New Jersey is comparatively young. And the results were, again, an extraordinary surprise.

The judges rated the wines in two flights, the first with white wines and the second with reds, using a 20-point scale. The French wines selected were from the same producers as in 1976 and included Chateau Mouton-Rothschild and Chateau Haut Brion, with prices up to $\$ 650$ wholesale per bottle. The New Jersey wines were selected by an informal panel of judges, who did not participate in the final tasting. The selections were made, from submissions by local wineries. In the case of the reds, the selections were made from wines made with New Jersey grown vinifera grape varieties that are commonly used in Bordeaux (cabernet, cabernet franc,

\footnotetext{
${ }^{a}$ Economics Department, Industrial Relation Section, Firestone Library, Princeton University, Princeton, NJ 08544-2098. email: c6789@princeton.edu.

${ }^{\mathrm{b}}$ Economics Department, New York University, $19 \mathrm{~W} 4^{\text {th }}$ St, 6 Fl, New York, NY 10012. email: karl. storchmann@nyu.edu.
} 


\section{Table 1}

\section{Wine Judges at the Judgment of Princeton}

Jean-Marie Cardebat

Tyler Colman

John Foy

Olivier Gergaud

Robert Hodgson

Linda Murphy

Danièle Meulders

Jamal Rayyis

Francis Schott
Professor of Economics, University of Bordeaux 4

www.DrVino.com

Wine Columnist, The Star Ledger; www.thewineodyssey.com

Professor of Economics, BEM Bordeaux Management School

Fieldbrook Winery, California

Co-author of American Wine; Decanter

Professor of Economics, Université Libre de Bruxelles

Gilbert \& Gaillard Wine Magazine

Stage Left Restaurant, New Brunswick; RestaurantGuysRadio.com

Table 2

Wines Tasted at the Judgment of Princeton

\begin{tabular}{|c|c|c|c|}
\hline \multicolumn{3}{|c|}{ White Wines } & Red Wines \\
\hline A & Heritage Chardonnay $2010(\mathrm{NJ})$ & A & Ch. Montrose $2004(\mathrm{~F})$ \\
\hline B & $\begin{array}{l}\text { Unionville Pheasant Hill Single Vineyard } \\
\text { Chardonnay } 2010 \text { (NJ) }\end{array}$ & B & Ch. Mouton Rothschild 2004 (F) \\
\hline $\mathrm{C}$ & $\begin{array}{l}\text { Puligny Montrachet Domaine Leflaive } \\
2009 \text { (F) }\end{array}$ & $\mathrm{C}$ & Silver Decoy Cab. Franc 2008 (NJ) \\
\hline $\mathrm{D}$ & Clos des Mouches Drouhin $2009(\mathrm{~F})$ & $\mathrm{D}$ & Heritage Estate BDX $2010(\mathrm{NJ})$ \\
\hline $\mathrm{E}$ & $\begin{array}{l}\text { Silver Decoy Black Feather Chardonnay } \\
2010 \text { (NJ) }\end{array}$ & $\mathrm{E}$ & Bellview Lumière 2010 (NJ) \\
\hline $\mathrm{F}$ & Bellview Chardonnay 2010 (NJ) & $\mathrm{F}$ & $\begin{array}{l}\text { Tomasello Cabernet Sauvignon } \\
\text { Oak Reserve } 2007 \text { (NJ) }\end{array}$ \\
\hline G & Ventimiglia Chardonnay 2010 (NJ) & G & Ch. Léoville Las Cases 2004 (F) \\
\hline $\mathrm{H}$ & $\begin{array}{l}\text { Meursault-Charmes Jean Latour-Labille } \\
2008 \text { (F) }\end{array}$ & $\mathrm{H}$ & Amalthea Europa VI 2008 (NJ) \\
\hline I & Amalthea Chardonnay 2008 (NJ) & I & Four JG's Cabernet Franc 2008 (NJ) \\
\hline $\mathrm{J}$ & $\begin{array}{l}\text { Bâtard Montrachet Marc-Antonin Blain } \\
2009 \text { (FR) }\end{array}$ & $\mathbf{J}$ & Ch. Haut Brion 2004 (F) \\
\hline
\end{tabular}

merlot, and petit verdot). In the case of the whites, the selections were made from New Jersey grown chardonnay grapes.

Tables 1 to 4 list the wines in each flight and their respective letter ID, the names and affiliations of the judges and the raw results.

Although, the average of the point scores and the Borda (average rank order, based on "points against") winner in each category was a French wine (Clos de Mouches for the whites and Mouton-Rothschild for the reds) New Jersey wines received very similar scores. In fact, as several analyses in this issue show, the French and New Jersey wines at the tasting were, on average, statistically indistinguishable. This is a remarkable result given that the prices for the New Jersey wines averaged only $5 \%$ of these top French wines. 
Table 3

Ratings for White Wines

\begin{tabular}{lllllllllll}
\hline Judge & $A$ & $B$ & $C$ & $D$ & $E$ & $F$ & $G$ & \multicolumn{1}{c}{$H$} & \multicolumn{1}{l}{$I$} & \multicolumn{1}{l}{$J$} \\
\hline Jean-Marie Cardebat & 10 & 13 & 14 & 15 & 8 & 13 & 15 & 11 & 9 & 12 \\
Tyler Colman & 16 & 14 & 14 & 16 & 12 & 11 & 11 & 14 & 11 & 14 \\
John Foy & 16 & 17 & 16 & 15 & 14.5 & 14.5 & 16 & 17 & 15 & 17.5 \\
Olivier Gergaud & 14 & 19 & 12 & 10 & 19 & 18 & 17 & 16 & 18 & 14 \\
Robert Hodgson & 17 & 11 & 13 & 14 & 14 & 10 & 9 & 9 & 10 & 10 \\
Linda Murphy & 15.5 & 15 & 17 & 18 & 16 & 17 & 15 & 14 & 16 & 17 \\
Danièle Meulders & 10 & 15 & 12 & 12 & 15 & 14 & 15 & 12 & 15 & 12 \\
Jamal Rayyis & 16 & 15 & 14.5 & 17.5 & 16.5 & 14 & 12 & 15 & 13 & 12 \\
Francis Schott & 17 & 16 & 12 & 18 & 15 & 16 & 15 & 14 & 17 & 15 \\
\hline
\end{tabular}

Table 4

Ratings of Red Wines

\begin{tabular}{lllrlllllll}
\hline Judge & $A$ & $B$ & $C$ & $D$ & $E$ & $F$ & $G$ & $H$ & \multicolumn{1}{l}{$I$} & $J$ \\
\hline Jean-Marie Cardebat & 15 & 11 & 12 & 16 & 14 & 11 & 14.5 & 13 & 10 & 14.5 \\
Tyler Colman & 14 & 11 & 16 & 12 & 14 & 13 & 14 & 12 & 13 & 11 \\
John Foy & 17.5 & 19 & 18 & 18 & 15 & 16 & 18 & 18 & 17 & 17.5 \\
Olivier Gergaud & 10 & 17 & 9 & 14 & 19 & 12 & 15 & 10 & 11 & 18 \\
Robert Hodgson & 13 & 17 & 13 & 16 & 12 & 15 & 10 & 12 & 8 & 11 \\
Linda Murphy & 13 & 14 & 17 & 16 & 15 & 17 & 14 & 15.5 & 13 & 18 \\
Danièle Meulders & 14 & 16 & 11 & 16 & 14 & 15 & 13 & 11 & 10 & 15 \\
Jamal Rayyis & 15 & 19.5 & 14 & 12 & 13 & 16 & 14.5 & 15 & 16 & 16 \\
Francis Schott & 19 & 18 & 8 & 15 & 15 & 12 & 15 & 16 & 7 & 17 \\
\hline
\end{tabular}

In this issue of the Journal of Wine Economics, we publish several papers inspired by the Judgment of Paris and the Judgment of Princeton.

The first paper is by George Taber, the only journalist at the original 1976 Paris Tasting, and author of the bestselling book, Judgment of Paris. Taber, also host of the Judgment of Princeton, sheds light on the events that led to the Princeton wine tasting and relates them to the Paris Tasting.

A statistical evaluation of the tasting, conducted by Richard Quandt, shows that the rank order of the wines was mostly insignificant. That is, if the wine judges repeated the tasting, the results would most likely be different. Judged from a statistical viewpoint, most wines were undistinguishable. Only the best white and the lowest ranked red were judged significantly different from the other wines. Additional analyses by Quandt can be found on the website of Liquid Assets (Quandt, 2012).

Daniel Ward analyzes the judges' scores from the Princeton Tasting to test for differences among the wines, but also to estimate the effects of judges sitting at the 
same table and to test for overall differences between wines from the two regions. The results indicate that the New Jersey and French wines do not, on average, differ in quality; and that the judges showed no signs of bias due to table seating.

Victor Ginsburgh and Israel Zang suggest a new game theory based ranking method for wines, in which the Shapley Value of each wine is computed, and wines are ranked according to their Shapley Values. Judges are not required to assign quality points or rank the tasted wines but only need to indicate their favorite wine(s). Ginsburgh and Zang apply the Shapley Value to the Judgment of Paris as well as to the Judgment of Princeton.

Drawing on several blind wine tastings Jeffrey Bodington analyzes whether the order of the wine within the flight influences the resulting rating. In contrast to, e.g., Ginsburgh and van Ours (2003), who found that the likelihood of winning a major piano competition is critically determined by the order of performance, Bodington does not find a similar effect in wine tasting.

The last three articles in this issue tackle issues that are unrelated to wine tasting and rating but focus on wine grape demand, wine's role in the development of economic thought, and on the U.S. beer industry.

Kate Fuller and Julian Alston examine the demand for California wine grapes. Employing a flexible-form inverse demand system model to estimate elasticities of demand for wine grapes from three grape-growing regions in California, representing three different price categories, they estimate own-price elasticities ranging from -2.6 for grapes in the low-price region to -9.5 for grapes in the highprice region.

Stephen Chaikind studies the role of wine in the development of economic thought and its contribution to modern economic theory. He highlights the role of enology and viticulture for the works of Adam Smith, David Ricardo, Karl Marx, John Stuart Mill, Léon Walras, Alfred Marshall, and others.

Jayendra Gokhale and Victor Tremblay analyze the relationship between price competition and market power for the U.S. brewing industry, especially for the time period after the mid 1990s. They find evidence that competition has diminished but not enough to substantially increase the market power of the few big players.

\section{References}

Ginsburgh, V.A. and van Ours, J.C. (2003). Expert opinion and compensation: evidence from a musical competition. American Economic Review, 93(1), 289-296.

Quandt, R.E. (2012). Tasting Report No. 161. Liquid Assets. Online at http://www. liquidasset.com/report161.html (last accessed October 29, 2012). 